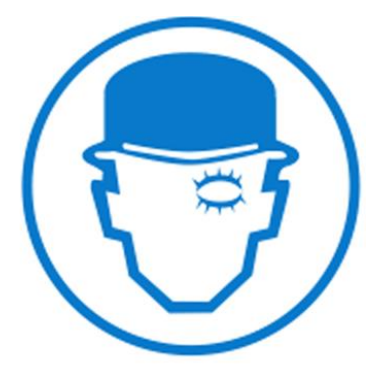

REVISTA TRANSGRESSÕES: CIÊNCIAS CRIMINAIS EM DEBATE, V.5, N.2,

MAIO DE 2017

\title{
PÁTRIA EXTERMINADORA: O PROJETO GENOCIDA BRASILEIRO.
}

Luciano Góes

Mestre em Direito pela Universidade Federal de Santa Catarina - UFSC (2015), professor do Centro Universitário Estácio de Santa Catarina e coordenador do núcleo jurídico do projeto de extensão "Vicente do Espírito Santo - S.O.S Racismo". Vice-presidente da Comissão de Igualdade Racial, Subseção de São José/SC, da Ordem dos Advogados do Brasil, Seccional Santa Catarina (OAB/SC) e secretário da Comissão da Verdade sobre a Escravidão Negra no Brasil da Ordem dos Advogados do Brasil, Seccional Santa Catarina (OAB/SC). Pesquisador/membro do projeto de Pesquisa e Extensão "Universidade Sem Muros - USM" (UFSC), no qual foi coordenador operacional em 2013, exercendo suas funções no interior do Presídio Feminino de Florianópolis/SC, do Grupo de Pesquisa Brasilidade Criminológica, ambos coordenados pela Prof. ${ }^{a}{ }_{\text {Dr. }}{ }^{a}$ Vera Regina Pereira de Andrade (UFSC/CNPq), e do Núcleo de Estudos Afro-Brasileiros do Centro Universitário Estácio de Santa Catarina (NEAB - Estácio). Advogado criminal.

Email: lglucianogoes@gmail.com

\section{RESUMO}

O presente artigo demarca um lugar de fala comprometido com uma Criminologia brasileira e seu realismo racial marginal, pretendendo lançar alguma luz na relação causa-efeito do extermínio massivo atual do negro com o racismo brasileiro, (re)definindo o genocídio como projeto político, histórico e ininterrupto, resultado de uma lógica exterminante congênita, explícita e implícita que possui na "guerra contra as drogas" sua mais nova legitimação, que expõe a programação racista de um sistema de controle racial/social. A força ideológica que mantém quase intacta e inalterável a estrutura racial socialmente estabelecida é reforçada constantemente pela pulverização da questão racial, que, apesar dos notórios resultados que o racismo confere ao nosso Direito Penal, não é situada como protagonista. Uma realidade que reforça nosso racismo com a política ideológica que sustenta o conto infantil do país das maravilhas raciais: sua não nomeação e não enfrentamento.

Palavras-chaves: Genocídio. Racismo. Criminologia brasileira. Realismo marginal.

"Como? Apenas abri os olhos que tinham vendado e já querem me afogar no universal? E os outros? Aqueles que "não tem boca", aqueles que "não tem voz". Tenho necessidade de me perder na minha negritude, de ver as cinzas, as segregações, as repressões, os estupros, as discriminações, os boicotes.

Precisamos botar o dedo em todas as chagas que zebram a libré negra." 


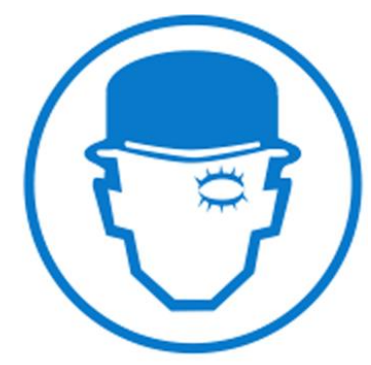

REVISTA TRANSGRESSÕES: CIÊNCIAS CRIMINAIS EM DEBATE, V.5, N.2, MAIO DE 2017

\section{INTRODUÇÃO}

Tendo como marco inicial a Criminologia crítica periférica e seu acúmulo construído até então, alertamos que em nossa marginalidade, nossa natureza colonizada norteou um disciplinamento manipulado pela violência física, instrumentalizado por infindáveis meios, em especial, como demonstração de força e propriedade absoluta do "sinhô" sobre o corpo negro inerte, que projeta(va) também o medo através do "mal exemplo".

Um hábito corriqueiro que atravessou séculos impulsionando o genocídio através do racismo, nosso pilar estrutural principal que, por tal razão, orienta a criminalização e a morte negra que tangencia toda nossa história, continuadamente (re)legitimado e construído pela dialética político-sociológica com objetivos bem definidos pela relação objetificador $\mathrm{x}$ objet(ificad)o.

Fundamentados na decolonialidade que estrutura o saber criminológico libertário latino, do lugar de fala de uma Criminologia brasileira, rechaçamos qualquer "novidade" que o termo genocídio possa induzir, pois, resultado do racismo brasileiro, se apresenta como processo político ininterrupto de extermínio do negro, cuja última legitimação é nossa "guerra contra as drogas" fundamentada na "saúde pública" que se traduz, na prática, em uma guerra racial declarada, tanto em relação ao seu "campo de batalha" quanto ao inimigo.

Nesse contexto, a morte cotidiana de 83 jovens negros ${ }^{1}$ e as constantes chacinas comovem e mobilizam apenas uma parcela da população brasileira, exatamente e principalmente a que vê sua existência sob risco iminente pela transformação, em fator criminógeno/genocida, que o conceito "raça" sofreu e que há muito foi consolidada pela banalização do extermínio dessa "quase gente".

Ignorar a questão racial é reforçar nosso racismo pela política assimilacionista de não enfrentamento e com ele a sistemática de nossos "Direitos Penais", a esquizofrenia racial que possibilita a imediata identificação da "clientela" da $3^{\mathrm{a}}$ maior população encarcerada do mundo, enquanto ignoram-se os reflexos de quase 400 anos de escravidão, como se estes

\footnotetext{
${ }^{1}$ Dados da ONG Anistia Internacional - Brasil que embasam a campanha "Jovem negro vivo".
} 


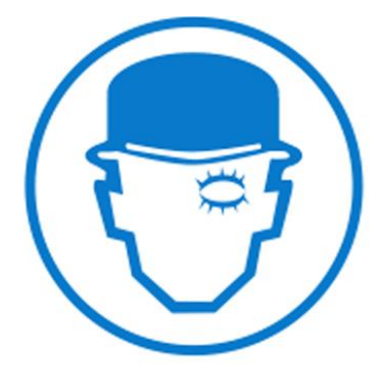

REVISTA TRANSGRESSÕES: CIÊNCIAS CRIMINAIS EM DEBATE, V.5, N.2, MAIO DE 2017

desaparecessem, num piscar de olhos, com a falsa abolição daquele sistema. Um efeito sem causa que delineia nosso controle racial/social e sua programação racista.

Delineando um realismo racial marginal, explicitamos os resultados de um extermínio congênito, que apresenta singularidades que o mantém praticamente incólume por sua negação que ecoa em coro, como um mantra que deve ser repetido na esperança que desapareça, sem nunca ter sido enfrentado, salvo em termos genocidas.

A força ideológica que mantém quase intacta a estrutura racial de um mundo branco construído por mãos negras, é (re)legitimada pela ignorância quanto ao problema racial radical(izado), fruto do conto infantil "que ainda seduz:" "Brasil: o país das maravilhas raciais" e da dissolução da questão racial em conflitos de classes oriundos de um capitalismo tardio que fomentam críticas ao "falido e disfuncional" Direito Penal declarado enquanto aumentam o déficit, pois desde nosso des(en)cobrimento vivemos em uma sociedade que não foi projetada nem preparada para tratar o negro como igual, para quem restou aquela "ninguendade" (RIBEIRO, 1995, p. 131) que foi (é) reconhecida e transmitida como herança em um mundo onde apenas uma raça monopoliza o poder, mantendo os instrumentos de dominação e as violências.

Esse cenário toma a feição de holocausto que se avulta sobre a juventude negra ao discutir-se a redução da maioridade penal e, mais recentemente, as alterações significativas no Estatuto do Desarmamento. A redução da maioridade penal está visceralmente ligada aos demais temas transversais trazidos e demonstra quão funcional é o paradigma racialetiológico em nossa sociedade ao ser defendido e fortalecido pelo "clamor popular" que manipula o Direito Penal como instrumento de vingança nomeando-a de "justiça".

Desvelar algumas feridas históricas abertas pelo racismo (jamais tratadas e ainda expostas) é o norte destas linhas. Esse processo objetiva o reconhecimento da política genocida nacional, transformando-o em projeto político de conscientização e empoderamento, uma posição que traz consigo o impulso transformador do controle racial/social marginal.

\section{PROJETANDO O HORIZONTE DA PROBLEMÁTICA RACIAL}




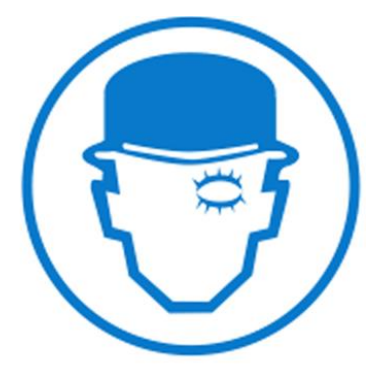

REVISTA TRANSGRESSÕES: CIÊNCIAS CRIMINAIS EM DEBATE, V.5, N.2, MAIO DE 2017

"O homem branco cometeu os piores e mais violentos crimes da história, mas de alguma forma eles conseguiram convencer o mundo que os negros é que são a grande ameaça."

(Michael Moore)

Muito antes do desembarque em nossa margem do capitalismo tardio (e com ele dos conflitos entre classes sociais, ou seja, de cunho materialista), a questão racial já encontrava um enraizamento profundo que nos reporta para além do centro, em direção à história não oficial da humanidade, considerando que a história é contada a partir do ponto de vista dos vencedores, ou melhor, dos exterminadores.

Os indícios do nascimento do racismo, enquanto instrumento de dominação, são dispostos por Carlos Moore (2007) ao apontar para a prática discriminatória do negro por quem acabara de deixar de sê-lo: o amarelo e o branco, renegando suas ancestralidades africanas por conta da alteração fenotípica resultante de fatores geográficos, climáticos e biológicos, dentre outros, muito antes da criação da Europa, fundada a partir do olhar branco que atravessou o negro, sem vê-lo, ignorando sua humanidade ao objetificá-lo com fins comerciais, base do colonialismo que transformou, segundo Achille Mbembe (2011), a ideologia racial em política genocida imprescindível à inauguração da ordem mundial: a necro-política diaspórica.

É dizer que o racismo é ontológico, estrutural, estruturante e condicionante de relações de todo o Ocidente, arquitetado sob a concepção de raças, construções políticassociais (NASCIMENTO, E., 2007) enraizadas em uma "superioridade" (re)legitimada sistematicamente que dispensa, hoje, qualquer fundamentação, mantendo-se pelas práticas hierarquizantes, funcionais à manutenção da estrutura desigual.

Com a configuração da “Améfrica Ladina”, formulada por Lélia Gonzalez (1988), as estruturas racializadas foram herdadas por nossa margem, edificando um mundo branco por mãos negras, e consolidando um ethos de não-humanos. Esse "legado" interiorizou em todo colonizado o sonho senhorial (e seu paradigma objetificante), lecionado por Frantz Fanon (FANON, 1968, p. 39), de obter o poder "absoluto" sobre o corpo negro coisificado, a condição basilar do reconhecimento social na periferia. 


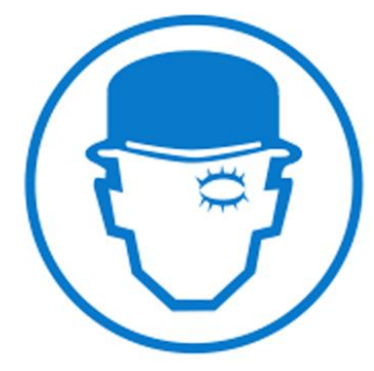

REVISTA TRANSGRESSÕES: CIÊNCIAS CRIMINAIS EM DEBATE, V.5, N.2, MAIO DE 2017

Instrumentalizando toda a violência aprendida em sua vivência, cada colonizado, ao tornar-se a "quintessência do mal” (FANON, 1968, p. 39), se projeta em uma aproximação a Deus, invocando seu poder natural de decisão sobre o destino alheio. Transmutado em senhor, toda e qualquer manipulação sobre (e a partir do) objeto negro é autorizada, sua vida, morte ou morte em vida, é um ato que prescinde de qualquer justificativa, uma espécie de ato sacrificial cuja obrigação de dar uma resposta é inexistente (MBEMBE, 2014, p. 70).

Logo após nosso "descobrimento", como Portugal não encontrou metais e pedras preciosas, seu interesse na gigantesca vastidão territorial de sua mais nova colônia se deu, em um primeiro momento, na extração vegetal cuja mão-de-obra já se encontrava coisificada em suas colônias na Costa Ocidental Africana, "santificadas" desde o início do século XV por Bulas papais que determinaram a propriedade exclusiva da raça negra à coroa portuguesa, tendo por fundamento a maldição bíblica de Cam (um dos filhos de Noé).

Nosso racismo, assim, se legitimou primeiro na benção católica, fundadora dos países ibéricos face às inúmeras invasões mouras e sua expulsão na Reconquista, um conflito entre o Islamismo e o Cristianismo, do negro (mouro) versus o branco, onde a expulsão daqueles caracterizou não apenas a vitória, mas a "superioridade" europeia (FLAUZINA, 2006, p. 31).

Nesse norte, ainda no início do século XVI, quando os primeiros negros aqui desembarcaram, sua força de trabalho foi direcionada para a extração do pau-brasil, nosso primeiro produto tipo exportação, que na Holanda manufatureira foi utilizado na "correção" dos prisioneiros nas Rasp-huis, gênese do disciplinamento no sistema prisional central (MELOSSI; PAVARINI, 2010, p. 43).

O sistema escravagista brasileiro, maior, mais duradouro e mais importante do mundo (FREITAS, 1991, p. 11), possibilitou o desenvolvimento e acumulação de capital europeu direta e indiretamente, já que todas as potências centrais seguiram a sombra espoliadora portuguesa, culminando com a Conferência de Berlim (1884-1885), onde o chanceler alemão Otto Von Bismarck formalizou a partilha da África entre os 14 países europeus participantes. Remodelando a ordem mundial ao invocar um "direito de conquista", o continente foi sentenciado à realidade hoje encontrada (BOAHEN, 2010). 


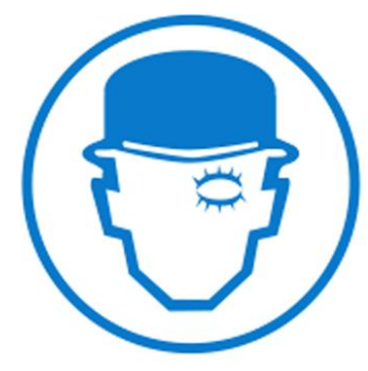

REVISTA TRANSGRESSÕES: CIÊNCIAS CRIMINAIS EM DEBATE, V.5, N.2, MAIO DE 2017

Abdias do Nascimento (1978) leciona que a morte física é apenas uma faceta do projeto genocida brasileiro. O extermínio do "Ser negro", a partir do processo "ninguenzador" (derivado da ninguendade que nos fala Darcy Ribeiro) iniciado, ainda, no colo da mãe África com a "Árvore do Esquecimento", foi complementado nos navios tumbeiros pelo medo branco da revolta negra que demandou a separação minuciosa das "coisas" oriundas da mesma região, objetivando impedir qualquer comunicação. Um movimento dinâmico de exclusão-inclusão que metamorfoseou a heterogeneidade continental africana em simples silogismo escravo-negro (DUARTE, 2011, p. 69), a total negação do direito à identidade, desde sua ancestralidade, do negro brasileiro.

Em meados do século XIX, objetivando a manutenção de uma sociedade racialmente estruturada, foi criada a Lei da Terra (Lei $n^{\circ}$ 601/1850), definindo que as terras ainda não ocupadas passavam a ser propriedades do Estado e as já ocupadas podiam ser regularizadas como propriedades privadas, garantindo os interesses da elite e aniquilando a possibilidade de ocupação de terras produtivas pelos negros, livres e libertos.

Nesse período, a própria existência da "raça primitiva" (abaixo, portanto, da "raça inferior" - os indígenas que tiveram sua alma reconhecida pela igreja católica, ao contrário dos negros) foi considerada como obstáculo ao desenvolvimento e progresso da nação, fundamentando a necessidade de branquear o país, aprumando-o rumo à civilização, norte apontado pela bússola "evolucionista" darwiniana.

O branqueamento nacional, assim, é outra faceta do nosso genocídio, e desta ótica, a Lei da Terra cumpria papel importante e fundamental para o futuro racial do país, sendo um projeto embrionário do clareamento da nação, pois em seu art. 18 estabelecia:

O Governo fica autorizado a mandar vir annualmente á custa do Thesouro certo numero de colonos livres para serem empregados, pelo tempo que for marcado, em estabelecimentos agricolas, ou nos trabalhos dirigidos pela Administração publica, ou na formação de colonias nos logares em que estas mais convierem [...]. [sic]

A imperiosidade de branquear o país, aliada à produção de açúcar pela Holanda, obrigou o Estado a "importar" mão de obra qualificada para produção de café, momento no

\footnotetext{
${ }^{2}$ Plantada em 1727 por Agadja, "O Conquistador", quinto rei do Daomé - atual Benim. Antes de embarcarem para além-mar, rumo ao "Novo Mundo", os cativos andavam em torno da árvore (negros nove vezes e negras sete). Cada volta representava a morte da história de seu povo, de sua história, raízes, subjetividade, memórias, lembranças, laços, etc.
} 


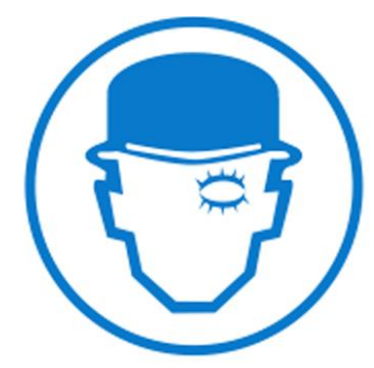

REVISTA TRANSGRESSÕES: CIÊNCIAS CRIMINAIS EM DEBATE, V.5, N.2, MAIO DE 2017

qual "a imigração passou a ser amplamente subsidiada e estimulada, os gastos com transportes e com a instalação eram financiados pelo Governo, que chegava até a promover obras para poder oferecer trabalho aos estrangeiros" (KAUFMANN, 2007, p. 78). A conjuntura política interna e externa do Brasil tornou o regime escravocrata insustentável e, sem o apoio dos escravagistas, o Império também se findaria.

Fundamentado nos ideais iluministas e liberais, o Movimento Abolicionista, presente desde 1823, ganha força no pós-guerra do Paraguai (1864 - 1870), quando milhares de escravos foram liberados para o front sob a promessa de que se retornassem vivos, seriam livres $^{3}$; enviados em troca de títulos de nobreza ou substituindo os filhos dos fazendeiros, mas em verdade, foram utilizados como "bucha de canhão" em uma cilada genocida, já que a guerra serviu, primordialmente, para desnegrecer o país, exterminando $60 \%$ da população negra entre os anos de 1860 e 1875, enquanto que a população branca cresceu 1,7 vezes (DUARTE, 2011, p. 173).

Com essa redução significativa, o branqueamento, como extermínio da gênese negra, se torna uma das bandeiras do "abolicionismo de resultados" (BATISTA, V., 2003, p. 180) que foi, de fato, um instrumento de controle racial, limitando ao mínimo sua extensão e efeitos, reduzindo ao máximo os riscos de uma transição do escravismo para uma república excludente. Um projeto esquadrinhado ao longo de 65 anos, para uma abolição puramente formal e profundamente falsa. Uma "liberdade" presenteada, embalada em papel jurídico pelo paternalismo branco, mantendo o negro controlado através da petrificação de seu lugar e status.

O dia 14 de maio de 1888, quando enfim a questão social (resultante dos conflitos originários entre classes) encontra a racial, marca o momento de convergência entre a teoria liberal e a prática racista, o inevitável conflito entre o branco e o negro em um mundo que foi construído para tratar o negro como um inumano (NASCIMENTO, A., 1978, p. 48).

Os espaços públicos, onde a liberdade era monocromática, passaram a contar com a presença negra indesejada e os métodos de controle racial, ordenados por um Direito penal de viés doméstico (BATISTA, N., 2002), ultrapassaram os limites fazendários seguindo seus

\footnotetext{
${ }^{3}$ O Decreto $n^{\circ} 3.725$-A, de 6 de Novembro de 1866, concedia liberdade gratuita aos escravos da Nação para se empregarem no exercito, e às suas mulheres, se fossem casados.
} 


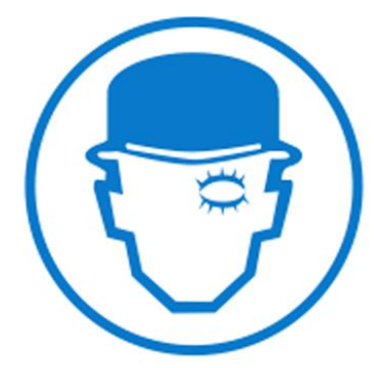

REVISTA TRANSGRESSÕES: CIÊNCIAS CRIMINAIS EM DEBATE, V.5, N.2, MAIO DE 2017

passos (tática do capitão do mato), impondo uma cisão no Direito penal brasileiro: ao lado do Direito penal declarado para os cidadãos, o Direito penal paralelo para os "subcidadãos", um sistema outrora identificado por Lola Aniyar de Castro (CASTRO, 2005, p. 96) como "subterrâneo" que em termos de Brasil jamais se ocultou, se expondo aos olhos de quem quiser enxergar.

Em 1890, o governo provisório fortalece a política de branqueamento ao promulgar o Decreto $\mathrm{n}^{\circ} 528$, que impedia não apenas a entrada de negros em solo nacional, mas também da "raça amarela". Entretanto, considerando o número de japoneses que chegou ao Brasil desde 18 de junho de 1908, a bordo do Kasato-maru, a proibição se restringia, de fato, aos africanos, e o sul do país seria a chave para a abertura das portas evolucionistas raciais da nação: a "Europa brasileira" ganhava contornos.

\section{NOSSO APARTHEID (MAL) MASCARADO: AS "NOVAS" LEGITIMAÇÕES PARA O VELHO CONTROLE RACIAL NO PÓS-ABOLIÇÃO.}

"O racismo não implica apenas a exclusão de uma raça por outra - ele sempre pressupõe que a exclusão se faz para fins de dominação."

(Steve Biko)

Um mundo branco desmoronando, à beira do caos, e estruturado sobre o racismo, necessitava urgentemente de uma nova legitimação que mantivesse a ordem racial intacta. Essa reestruturação ideológica viria pelas mãos da sciencia. Após a abolição, cerca de sete milhões de negros (FLAUZINA, 2015, p. 37), sem qualquer auxílio ou política governamental, foram expulsos das zonas rurais e excluídos das zonas urbanas, iniciando o processo massivo de favelização das grandes cidades, as senzalas a céu aberto, o primeiro "lugar do negro" (SANTOS, 2010).

A naturalização da ignorância e submissão foram impostas através desses espaços planejados geopoliticamente como "cidades armadilhas" (BATISTA, V., 2003, p. 36), onde esperou-se que a inexistência de condições de vida mantivesse a engrenagem mortífera funcionando. Uma zona de miserabilidade e violência que o Estado não apenas ignorou, mas promoveu com fins higienistas até bem pouco tempo, quando, revisitando sua raiz 


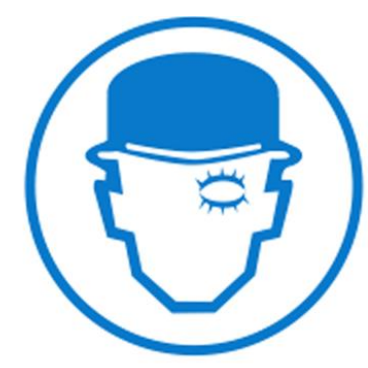

REVISTA TRANSGRESSÕES: CIÊNCIAS CRIMINAIS EM DEBATE, V.5, N.2, MAIO DE 2017

colonial/exterminadora portuguesa, "descobriu" esses territórios, subiu as vielas "sorrindo", impondo a "pacificação", fincando bandeira e demarcando território, demonstrando que o único direito dessa "(quase) gente" é ser objetificada, de incomensuráveis modos, todos banalizados e invisibilizados.

Nosso apartheid, já evidenciado pela dicotomia morro-cidade, expõe nossa excelência em excluir, reduzir, dizimar, impondo ao negro brasileiro a (re)construção de uma nova identidade a partir de espectros e fragmentos das inúmeras raízes africanas que aqui se homogeneizaram, e instrumentos de resistência e luta (samba, capoeira, religiões de matrizes africanas, etc.), estabelecendo o paradoxo do negro brasileiro: trazer a marca do escravizado à flor da pele enquanto carrega, em seu sobrenome, religião, "padrões", etc., a marca do escravizador.

O medo branco de uma nova revolta negra, após os levantes pretos de Palmares (1580-1716), Haiti (1791-1804), Malês (1835), Sabinada (1837-1838), Cabanagem (18351840), Balaiada (1838-1841), Farrapos (1835-1845 $)$, apenas para citar algumas, foi responsável pela criminalização de toda e qualquer manifestação que permitisse a reunião dos negros, pois esses "ajuntamentos" poderiam ser o germe da temida revolução.

Dentre os fundamentos para essas criminalizações, encontramos as premissas etiológicas potencializadas pelo álcool e pela maconha, conhecida à época como "fumo de negro" (SAAD, 2013), introduzida no país, de acordo com documento oficial do Ministério das Relações Exteriores brasileiro, datado de 1959 (CARLINI; RODRIGUES; GALDURÓZ, 2005, p. 23), pelos escravos, que trouxeram sementes da planta através das Abayomis. ${ }^{5}$

\section{RACISMO CRIMINOLÓGICO: BASE DO NOSSO CONTROLE RACIAL- MARGINAL.}

\footnotetext{
${ }^{4} \mathrm{O}$ maior conflito interno enfrentado pelo Império brasileiro contou, dentre os farroupilhas, com grande número de escravos. Em certos momentos do período, os lanceiros negros representaram metade do exército riograndense. Como de costume na história nacional, a participação e importância negra é ocultada, assim como a "entrega" dos lanceiros negros ao exército imperial, conforme acordo prévio para a assinatura do tratado de paz, denunciada pela Carta de Porongos. Findado o conflito, a ameaça negra forjada na e para a batalha teria que ser exterminada.

${ }^{5} \mathrm{Na}$ travessia do Atlântico, as escravas, para amenizar o sofrimento das crianças, rasgavam tiras de pano de suas saias e faziam bonecas para elas brincarem. A palavra abayomi tem origem no iorubá e significa aquela(e) que traz felicidade.
} 


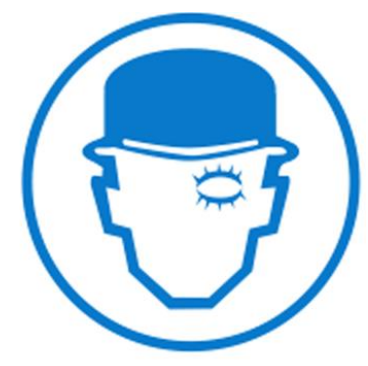

REVISTA TRANSGRESSÕES: CIÊNCIAS CRIMINAIS EM DEBATE, V.5, N.2, MAIO DE 2017

"O racista numa cultura com racismo é por esta razão normal. Ele atingiu a perfeita harmonia entre relações econômicas e ideologia."

(Frantz, Fanon)

É Eugenio Raúl Zaffaroni (1991, p. 77) quem ensina que na margem não é o modelo disciplinador benthamiano que caracteriza o controle social, mas sim o modelo lombrosiano, pois, aqui, o disciplinamento de mão de obra não derivou da demanda das fábricas.

A disciplina periférica sempre decorreu da necessidade de manutenção da ordem racial, instrumentalizada pelo açoite como força motriz que impulsionava a economia lastreada pelas mãos negras e alcançada sempre por meio de violentas agressões físicas e mortes, meios indispensáveis no controle racial que tem como objeto a domesticação do corpo e da alma, impondo a desumanização que assegura a exclusividade dos espaços pré-definidos.

Esse modelo, ideologicamente racista (estribado no primeiro livro do médico italiano L'uomo bianco e l'uomo do colore: letture sull'origine e la varietà delle razze umane, de 1871, no qual encontramos as matrizes para o paradigma etiológico), estabeleceu o marco para a construção de "apartheids criminológicos".

O primeiro apartheid contra os negros (camitas), legitimando o controle racial após abolição da escravatura de vários países e divisão do continente africano, e o segundo contra os judeus (semitas), estruturando o holocausto nazista, quando a ideologia racial, até então não combatida no cenário internacional (é dizer, naturalizada mundialmente), foi manipulada por Adolf Hitler (ZAFFARONI, 1988, p. 191). Ou seja, o racismo apenas se tornou problemático e preocupante, impondo enfrentamento e "solução", quando fundamentou o nazismo e o fascismo, ameaçando, assim, a raça branca.

Mesmo em descrédito no Centro, pelas fortes críticas que nem ao menos arranharam superficialmente seu paradigma racial (que impeliram Lombroso a substituir o positivismo pelo espiritismo, ideologias que comungam a mesma fundamentação racista), suas ideias foram "traduzidas", não por coincidência, no Brasil exatamente no contexto pós-abolição, quando seus rumos ficaram a cargo dos "homens de sciencia", representada por nossa elite ilustrada que se espelhava no Centro (uma imagem mal refletida, mas que ainda assim, 


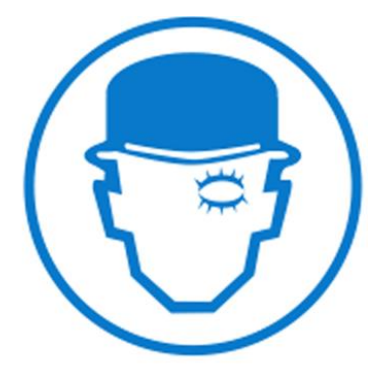

REVISTA TRANSGRESSÕES: CIÊNCIAS CRIMINAIS EM DEBATE, V.5, N.2, MAIO DE 2017

hipnotizava), primeiro aderindo à "moda" e depois produzindo e praticando ciência (SCHWARCZ, 2012, p. 41-42).

O processo de tradução da teoria lombrosiana assegurou sua funcionalidade, caracterizada como uma verdadeira "metamorfose" (SOZZO, 2014), pois foi orientado pelo viés racista que traçou a evolução humana a partir dos primatas, sendo os negros o elo perdido entre aqueles e o ápice evolutivo humano: o branco europeu. Nesse trajeto, o negro traria como herança (indireta pelo atavismo ou direta pela hereditariedade) a inferioridade, a impulsividade e a degeneração que o ligaram, de modo indissociável, ao elemento perigoso: o criminoso.

O "hibridismo quase incestuoso" (GENELHÚ, 2012, p. 58) do saber médico (legitimado como salvacionista nacional e único saber verdadeiro) com o direito penal, ambos imbuídos e norteados pelo racismo que orientou(a) a limpeza social com políticas higienistas e sanitaristas a serviço daquela macropolítica de branqueamento nacional, marcaram o ritmo e os objetivos dos processos de "tradução" do lombrosianismo.

Nina Rodrigues traduziu a teoria resgatando sua matriz racista, diluída em L'Uomo Delinquente (o que não significa ausente, muito pelo contrário) reforçando-a e potencializando-a com o ecletismo teórico-racial central, substituindo o estereótipo central (perante o qual poderia ser identificado como criminoso, pois mestiço) pelo fenótipo negro, pregando a arianização como solução única para o Brasil.

Apontando os erros da adoção dos pressupostos metafísicos do Classicismo em "As raças humanas e a responsabilidade penal no Brasil", o médico esboça e propõe a formalização de um apartheid brasileiro de cunho eugênico, um discurso pessimista e mimético ao central que por muito pouco não foi implementado, sendo superado pela influência e prestígio dos juristas paulistas perante o governo.

Naquele momento, o Brasil vivia intensamente o medo da "africanização" (BATISTA, V., 2003, p. 163) e da mestiçagem (que já tomara conta de certas regiões do país), sendo compreendida aqui "[...] de forma ambígua: apesar de temida, nela se encontrava a saída controlada [...]" (SCHWARCZ, 2012, p. 161). Era a ideia da "boa miscigenação", 


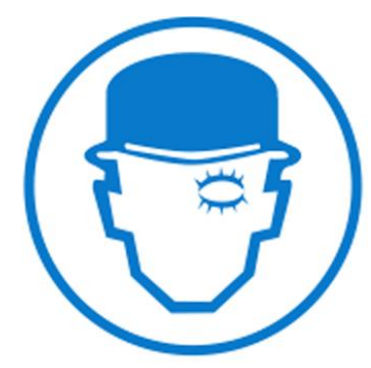

REVISTA TRANSGRESSÕES: CIÊNCIAS CRIMINAIS EM DEBATE, V.5, N.2, MAIO DE 2017

gestada pela ciência marginal, que interpretou a teoria original de modo singular, marco de uma ciência à brasileira.

Entretanto, se não conseguiu influenciar as políticas públicas para a desafricanização nacional, Nina Rodrigues nos mostra como o racismo atravess(a)ou ileso toda a história do Brasil, tangenciando todas as transições políticas e sociais, pois é exatamente na prática que a ordem racial é mantida, independentemente dos discursos teóricos adotados, positivados legal ou constitucionalmente, todos simples fachada.

Em sua obra "Os africanos no Brasil", é esclarecedor como o problema negro é representado, refletindo o cenário nacional ao incorporar uma esfinge, lançando seu enigma: “decifra-me ou devoro-te!”. A aterrorizante africanização se avulta e o fracasso do extermínio total do negro cobra uma solução, o genocídio toma o rumo político da tolerância ${ }^{6}$, uma nova fase do processo de branqueamento, agora direcionado à alma do negro.

Uma política silenciosa e hierarquizante a partir da proximidade com os brancos e aceitação acrítica de seus padrões (e, por consequência, afastamento e negação da origem negra). Era dizer: nem todo negro seria um negro, se não demonstrado fisicamente ao menos na alma (o famoso "negro de alma branca"). Dividir para conquistar, essa (é) era a tática!

Outra importante "tradução" do paradigma racial-etiológico lombrosiano demonstra que o racismo é a face oculta(da) da nossa "guerra contra as drogas", disposta, constantemente, como sendo um engajamento nacional ao programa estadunidense de combate ao comércio de drogas consideradas ilícitas, que colocou, teoricamente, a questão sobre termos de saúde pública, mas explicitando a lógica do extermínio.

Ao contrário do que induz a ideia de "coligação", o combate às drogas consideradas ilícitas em nosso país foi inaugurado na década de 1930, pela intensificação militar no combate ao "comércio" da planta. Em 1932, o comércio e consumo de maconha (diamba) foram considerados ilícitos pelo Decreto $\mathrm{n}^{\circ}$ 20.930, cuja imprescindível fundamentação científica decorreu do estudo pioneiro sobre a planta "Os fumadores de maconha: efeitos e males do vício", de 1915, do também médico Rodrigues Dória.

\footnotetext{
${ }^{6}$ Ato de suportar algo, ou alguém, denotando a relação hierárquica verticalizada pelo sacrifício de consentir uma presença incômoda, inaceitável.
} 


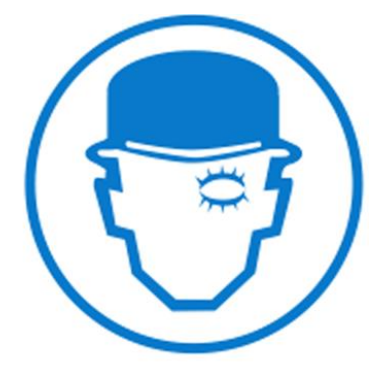

REVISTA TRANSGRESSÕES: CIÊNCIAS CRIMINAIS EM DEBATE, V.5, N.2, MAIO DE 2017

Destarte, desde sua proibição o que se combate não é (e nunca foi) a periculosidade toxicológica da droga, mas os negros, pelo seu uso religioso, curativo ou por seu simples consumo como instrumento de fuga de um mundo extremamente violento (tal qual o uso do álcool), no qual a (sobre)vivência era quase insuportável. Uma nova legitimação para o velho genocídio com a criminalização do "fumo d'Angola" e sua consolidação como instrumento de dominação racial.

A Criminologia Positivista, aliada à institucionalização do racismo pelo Estado, forneceu a legitimidade científica para manter a estrutura racial intocável, a violência, a subjugação e o genocídio, modernizado por nossa "guerra contra as drogas" como controle racial dos não-brancos brasileiros, protegendo os brancos não-europeus (mas que assim deseja(va)m ser).

A abolição da escravatura representou uma igualdade que não ilumina(va) os negros, que somente eram (são) cidadãos perante o Direito Penal, mantendo a funcionalidade daquela “dualidade perversa" (BATISTA, N., 2002, p. 152) propulsora da seletividade penal inversa que concretiza a imunidade (BARATTA, 1993, p. 49-50) muito bem conhecida quanto aos crimes raciais (racismo e injúria racial), consolidando a perfeição deste crime, conforme leciona Kabengele Munanga, por não haver lesão, vítima, provas, indícios ou mesmo, vestígios, tudo decorrente da "vitimização" e de um "complexo de perseguição".

A partir de Alessandro Baratta (BARATTA, 2011), com a explicitação da imprescindível reação social no processo de construção do "criminoso" estabelecida pelo Labeling Approach, deslocando-se a questão para o racismo como fonte originária de conflitos e definidor de lugares transmitidos como herança em nossa margem, emerge, de pronto, o confronto racial e o monopólio do poder (des)criminalizante nas mãos da raça/classe dominante em definir o que é e o que não crime de racismo, quem é e quem não racista.

O direito penal desigual, nesse plano, é transformado em instrumento a serviço da branquitude, um presente conferido ao branco por um mundo branco, corolário de inúmeros privilégios, concretos e simbólicos (SCHUCMAN, 2014), significando imunização criminológica de seus pares, esvaziando a tutela constitucional. 


\section{A ASSIMILAÇÃo RACIAL: ENFIM, O SUCESSO DA POLÍTICA GENOCIDA BRANQUEADORA!}

"Quando o rebanho se une, o leão vai se deitar com fome."

(Provérbio Africano)

Abolida a escravatura, nosso racismo foi redefinido. Antes estribado na superioridade racial endossada cientificamente, agora se orientava pelo preconceito de cor, cujo objetivo era apenas um: o de deixar o negro em seu devido lugar, a ponto de não poder ameaçar a exclusividade das posições sociais dos brancos.

Essa redefinição foi consequência do "fracasso" das políticas genocidas, das quais o negro "teimava" em sobreviver, sendo imperioso, assim, a criação de um novo instrumento de controle racial/social: a assimilação racial (mais sutil, porém não menos cruel), nossa resposta às nossas especificidades raciais que gestou o mito da "democracia racial", que possui uma superficialidade facilmente percebida, pois apenas uma raça monopoliza "[...] todo o poder em todos os níveis político-econômico-sociais: o branco" (NASCIMENTO, A., 1978, p. 46).

A política assimilacionista, formadora do conto Brasil: o país das maravilhas raciais, modelou o racismo brasileiro, que ganhou contornos singulares, inculcando em parte da população negra e sua descendência a vergonha da sua negritude com uma (falsa) promessa de facilitação de ascensão social sob a condenação à desigualdade, na qual a mobilidade vertical somente se opera por infiltração controlada, de modo eficaz, por "técnicas de dominação racial” que consistem “[...] literalmente, em obter a identificação desses indivíduos aos interesses e valores sociais da 'raça dominante"'( FERNANDES, 1972, p. 27).

A negação da ancestralidade importou em aceitação de modelos comportamentais e estéticos da raça dominante, perante a qual o fenótipo negro, ao se distanciar do padrão Barbie, materializa o "estereótipo do mal" (ZAFFARONI, 1988, 159). Entretanto, esse "pacto" não significou cumprimento das promessas brancas, pois, como estabelece Kabengele Munanga (1988, p. 30): “[...] o esforço do negro para tornar-se branco não obteve o sucesso que ele esperava. Vestidos à europeia, de terno, óculos, relógio e caneta no bolso do paletó, fazendo um esforço enorme para pronunciar adequadamente as línguas metropolitanas, os 


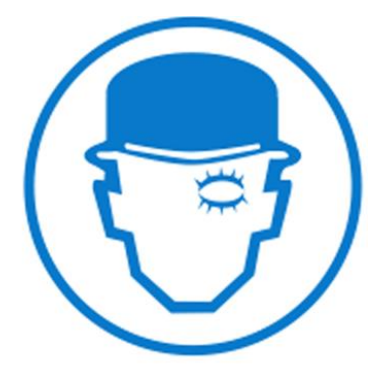

REVISTA TRANSGRESSÕES: CIÊNCIAS CRIMINAIS EM DEBATE, V.5, N.2, MAIO DE 2017

negros não deixavam de ser macaquinhos imitando homens". Seja como for, em qualquer posição social, um negro será (sempre) apenas, mais um negro!

Apesar da atraente (falsa) promessa de "inclusão", muitos negros, organizados ou não, não se deixaram ludibriar e utilizaram a matriz africana continental como instrumento identitário, unificador, de resistência e conscientização, transformando substancialmente o significado de "raça negra". Antes, indicativo de objetificação/inferiorização e motivo de vergonha, agora motivo de orgulho e símbolo de luta política, conscientização da negritude e empoderamento racial que fundamenta o desvelamento ou resgate das raízes identitárias roubadas dos que aqui foram objetificados, despersonalizados e, finalmente, desumanizados, base do Pan-africanismo ${ }^{7}$, fonte de relações aproximativas imediatas, vínculos (quase) parentescos explicáveis somente por uma história, geral e individual, (quase) sempre comum.

Entretanto, a ilusória proposta continu(a)ou a seduzir muitos negros que preferem fechar os olhos para a realidade racial explícita, não reconhecendo o racismo que ainda, como chibata, estala em suas costas. Posição decorrente da síndrome do escravo fiel cujo imperativo para uma mínima aceitação social passa pelo não enfrentamento e obediência servil ao sinhô.

O sucesso desse instrumento é demonstrado pela Pesquisa nacional por amostra de domicílios (PNAD) realizada pelo IBGE em 1976, na qual, ao responder à questão aberta sobre sua cor, o brasileiro forneceu 135 cores, uma clara tentativa de fugir do estigma racial. De igual modo e pelos mesmos motivos, esse sentimento ocorre em nossa magistratura, segundo o Censo do Poder Judiciário realizado pelo CNJ em 2014 (que já demonstra o racismo institucional, pois apenas $1,4 \%$ dos 16.812 juízes do Brasil se autodeclararam pretos), pois, é preferível ser pardo ${ }^{8}$ (declarado por $14 \%$ dos magistrados), do que assumir a sua negritude. É melhor ser considerado "sujo" ou "mulato" (filhote de mula) do que negro!

Legado do nosso racismo nada velado que alcançou finalmente, com a política branqueadora assimilacionista (sempre funcional), o sucesso exterminador da negritude do negro. É um genocídio articulado em uma dupla operacionalização, como nos ensina Abdias do Nascimento: o branqueamento pela miscigenação e a imposição da cultura eurocêntrica,

\footnotetext{
${ }^{7}$ Segundo Leila Leite Hernandez, o Pan-africanismo "é um movimento político-ideológico centrado na noção de raça, noção que se torna primordial para unir aqueles que, a despeito de suas especificidades históricas, são assemelhados por sua origem humana negra". (HERNANDEZ, 2005, p. 138).

8 "Branco-sujo". Dicionário on line UOL. Disponível em: http://michaelis.uol.com.br/moderno/portugues/.
} 


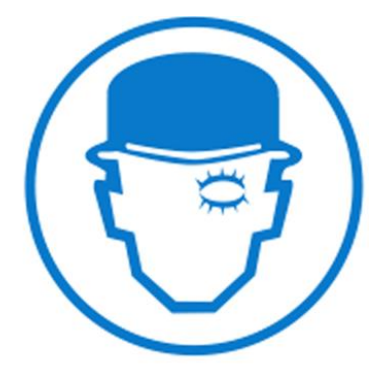

REVISTA TRANSGRESSÕES: CIÊNCIAS CRIMINAIS EM DEBATE, V.5, N.2, MAIO DE 2017

determinando a negação da ancestralidade pela interiorização do modo de viver e ser branco, ao mesmo tempo em que pró́be o negro de ser negro.

O medo branco continua a evitar, a todo o custo, a conscientização da negritude, por isso o racismo no Brasil é sempre negado, cedendo espaço nas discussões à farsa da "democracia racial", modelo tipo exportação elogiado e utilizado como exemplo pela ONU, onde chegou por mérito de Nina Rodrigues através de sua escola (CORRÊA, 2001), que nega o racismo e explicita a assimilação que “[...] só concebe aos negros um único 'privilégio': aquele de se tornarem brancos, por dentro e por fora" (NASCIMENTO, A., 1978, p. 93).

Esse é o posicionamento também de Darcy Ribeiro (1995, p. 226), que vê no apartheid ou no racismo estadunidense algumas vantagens, eis que esse "paraíso racial" é um golpe político que impede e dissolve a identidade coletiva, despolitizando o negro brasileiro, pois "o aspecto mais perverso do racismo assimilacionista é que ele dá de si uma imagem de maior sociabilidade, quando, de fato, desarma o negro para lutar contra a pobreza que lhe é imposta, e dissimula as condições de terrível violência a que é submetido".

Essa política segrega tal qual o apartheid sul-africano, muito bem representado aqui pelas respostas aos "rolezinhos" (impedindo acesso de jovens negros aos Shoppings ou expulsando-os de lá), pelas blitzes cariocas (que tornam as praias da zona sul "zonas seguras" pela exclusividade branca e para ela), e pela criação de tribunais raciais responsáveis por definirem regras de aferição da veracidade da autodeclaração prestada por candidatos negros para fins de concursos públicos.

Tais comissões da "pureza racial" foram (re)criadas pela Orientação Normativa $\mathrm{n}^{\circ} 3$, de $1^{\circ}$ de agosto de 2016, tendo como justificativa o "combate às fraudes" na reserva aos negros de $20 \%$ (vinte por cento) das vagas oferecidas nos concursos públicos para provimento de cargos efetivos e empregos públicos no âmbito da administração pública federal, das autarquias, das fundações públicas, das empresas públicas e das sociedades de economia mista controladas pela União, estabelecida pela Lei no $12.990 / 2014$, como política de ação afirmativa no combate ao racismo institucional.

Em seu art. $2^{\circ}, \S 1^{\circ}$, a orientação estabelece: "as formas e critérios de verificação da veracidade da autodeclaração deverão considerar, tão somente, os aspectos fenotípicos do 


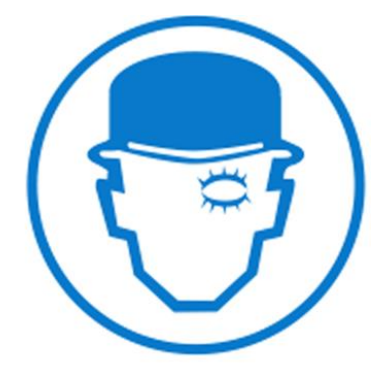

REVISTA TRANSGRESSÕES: CIÊNCIAS CRIMINAIS EM DEBATE, V.5, N.2, MAIO DE 2017

candidato, os quais serão verificados obrigatoriamente com a presença do candidato", e, em que pese em seu $\S 2^{\circ}$ determinar, como um dos requisitos para sua formação, a distribuição por cor entre os membros, a presença ínfima ou inexistente de negros nas instituições públicas fará com que o difícil e doloroso processo de construção e reconhecimento da negritude seja ignorado, negando, novamente, a identidade negra. O país da "democracia racial” confere ao branco o poder de dizer quem é negro.

O racismo cientifizado (re)utiliza seu arsenal epistemológico e moderniza os laboratórios antropométricos e frenológicos oitocentistas, discriminando as características do "verdadeiro" negro brasileiro, conforme tabela abaixo:
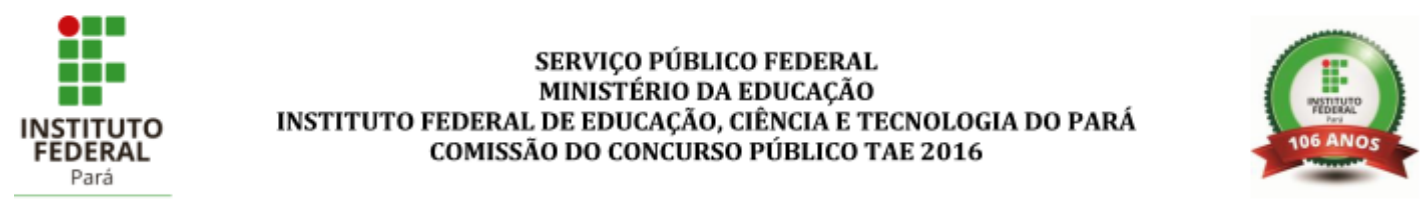

Anexo IV - Padrões Avaliativos

\begin{tabular}{|c|c|c|c|c|c|c|c|c|}
\hline \multicolumn{9}{|c|}{ Padrões Avaliados } \\
\hline \multirow{2}{*}{ Item } & \multirow{2}{*}{ Fenótipo } & \multirow{2}{*}{ Descrição do Negro } & \multicolumn{3}{|c|}{ Compatível } & \multicolumn{3}{|c|}{ Não Compatível } \\
\hline & & & A1 & A2 & A3 & A1 & $\mathbf{A 2}$ & A3 \\
\hline \multirow{3}{*}{1} & \multirow{3}{*}{ Pele } & 1.1. Melanoderma - Cor Preta & & & & & & \\
\hline & & 1.2. Feoderma- cor parda & & & & & & \\
\hline & & 1.3. Leucoderma - cor Branca & & & & & & \\
\hline 2 & Nariz & 2.1. Curto/largo/chato (platirrinos) & & & & & & \\
\hline \multirow{3}{*}{3} & \multirow{3}{*}{ Boca/dentes } & 3.1. Lábios grossos & & & & & & \\
\hline & & 3.2. Dentes muitos alvos e oblíquos & & & & & & \\
\hline & & 3.3. Mucosas roxas & & & & & & \\
\hline 4 & $\begin{array}{l}\text { Maxilar } \\
\text { (Prognatismo) }\end{array}$ & 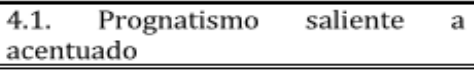 & & & & & & \\
\hline 5 & Crânio & $\begin{array}{l}\text { 5.1. Crânio dolicocélico }<74,9 \\
\text { (largo } 4 / 5 \text { do comp) }\end{array}$ & & & & & & \\
\hline 6 & Face & $\begin{array}{l}\text { 6.1. Testa estreita e comprida nas } \\
\text { fontes }\end{array}$ & & & & & & \\
\hline 7 & Cabelo & 7.1. Crespos ou encarapinhados & & & & & & \\
\hline 8 & Barba & 8.1. Barba pouco abundante & & & & & & \\
\hline 9 & $\begin{array}{l}\text { Arcos } \\
\text { Zigomáticos }\end{array}$ & 9.1. Proeminentes ou salientes & & & & & & \\
\hline
\end{tabular}

Tabela 01: Anexo IV, do Edital 07/2016 - Concurso público para provimento de cargos técnico-administrativos do Instituto Federal de Educação (IFPA).

Da leitura dos "requisitos" para considerar-se um candidato negro, emerge, de imediato, a lição de Cesare Lombroso sobre as evidentes desigualdades raciais que não 


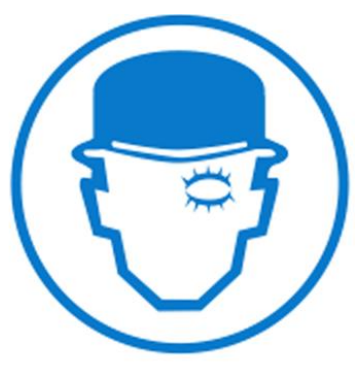

REVISTA TRANSGRESSÕES: CIÊNCIAS CRIMINAIS EM DEBATE, V.5, N.2, MAIO DE 2017

necessitavam de fundamentos científicos para a sua legitimação. A simples comparação entre o negro e branco era análoga à comparação do cão com um lobo ou entre um gato e um tigre. Essas diferenças hierárquicas eram ainda maiores se observados outros quesitos:

O crânio do europeu distingue-se por uma estupenda harmonia de formas: não é muito longo, nem muito redondo, nem muito pontudo ou piramidal. Na sua fronte, plana, larga, de face reta, lê-se, notadamente, a força e predomínio do pensamento: os zigomas ou botões da face não são muito distantes um do outro, e a mandíbula não se sobressai muito para o exterior: o que se intitula de ortognato. [...]. O negro e o australóide tem o crânio oblongo [possui mais comprimento do que largura], em forma de barquinho ou de feijão (dolicocéfalo) [crânio oval, com o diâmetro transversal um quarto menor que o longitudinal], e base da maxila inferior muito mais saliente para frente do nível do crânio, e por isto são chamados de prognatos ou de focinho saliente (LOMBROSO, 2012, p. 14-15).

Estabelecendo uma política de ruptura com o governo eleito democraticamente, o governo ilegítimo põe em prática seu plano de impedir o acesso dos negros aos cargos públicos mesmo não findando, de modo formal, com a política federal de ações afirmativas que resultou no pequeno, porém considerável, avanço na igualdade racial, "devolvendo" à raça/classe dominante uma parte seus privilégios perdidos com uma política determinante na “invasão” de espaços públicos pela população negra.

Sabedor dos riscos que a crescente conscientização e empoderamento negro representam, o lema da pátria precisa ser reforçado em prol da defesa e hegemonia branca: ordem e (para o) progresso (leia-se: tudo e todos em seus devidos lugares, e os lugares dos negros estão profundamente enraizados em nosso solo).

\section{A GUISA DE CONCLUSÃO: O GENOCÍDIO NOSSO DE CADA (E DE TODOS OS) $\operatorname{DIA}(\mathbf{S})$.}

"Assumimos uma luta que nos vincula aos abolicionistas que se opuseram à escravidão. As instituições da prisão e da pena de morte são os exemplos mais óbvios de como a escravidão continua a assombrar nossa sociedade."

(Angela Davis)

O extermínio negro é uma permanência em nossa história, um projeto político genocida que coloca o negro sempre em cena como vilão principal, mas nega o racismo como 


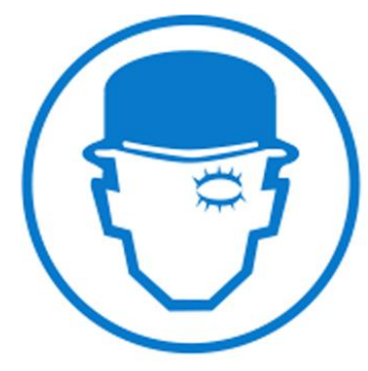

REVISTA TRANSGRESSÕES: CIÊNCIAS CRIMINAIS EM DEBATE, V.5, N.2, MAIO DE 2017

cenário (FLAUZINA, 2006, p. 41). Uma realidade que atravessa todos os sistemas penais e que representa a permanência funcional do Direito Penal escravagista-doméstico (BATISTA, N., 2002, p. 148), matriz indelével de nosso "Ornitorrinco punitivo" (ANDRADE, 2012, p. 111) que ainda tenta contabilizar os corpos daquela cifra negra. ${ }^{9}$

Nossa "guerra contra as drogas" conferiu continuidade ao genocídio negro, uma estratégia política que ganha cores vivas do nosso racismo ao colocarmos luz na construção dos "campos de batalha", dos inimigos de sempre (sempre alvos das balas nunca perdidas, que encontram facilmente o caminho em direção aos corpos negros) e no fundamento real escamoteado pela "saúde pública", explicitando uma guerra racial chancelada pelo Estado, não apenas legitimando as execuções, mas impulsionando e financiando o modelo exterminador das UPP's (Unidade Para matar Preto).

Vera Malaguti (BATISTA, V., 1998) explicita o ideário, construído e difundido pela programação racista, que impulsiona a seletividade racial, responsável, em parte, pela incursão no imaginário coletivo da figura perigosa do delinquente/traficante que, em seu olhar e postura orgulhosa, afronta e desafia os "homens da lei". O senso comum punitivista é um campo fértil para a proliferação e renovação do "fantasma negro" que atormenta os lindos sonhos dourados da "sociedade de bem", devendo ser exorcizado pela cruzada travada na margem da margem, um sintoma da barbárie transvestida de civilização, eliminando quem mais tem motivos para se posicionar e lutar por transformações (MENEGAT, 2012).

Nesse sentido, o extermínio cotidiano dessa figura demonizada encontra forte amparo na opinião públic(izad)a forjada por programas policialescos que formam sua audiência sobre o clamor da violência e do sangue, escamoteando, por força da aliança política com o conservadorismo, toda violência racial estrutural-institucional. A guerra contra a população negra não é exclusividade do Brasil, porém, seu sucesso não se observa pelos lucros, mas pelos mortos, diretos ou indiretos, sendo que em ambos é o Poder Executivo (na pior acepção da palavra) o responsável, atuando na (i)legalidade (in)visível.

\footnotetext{
${ }^{9}$ Ao contrário daquele conceito criminológico conhecido, o termo "negro" não pode ser mais usado em sentido pejorativo. Outrossim, utilizamos a nomenclatura "cifra negra" aqui em sua literalidade, como referência ao número real, e por isso incomensurável, que envolve todos os corpos negros resultante de uma histórica política exterminadora que teve início no nosso "descobrimento" e cujo fim não se observa no horizonte.
} 


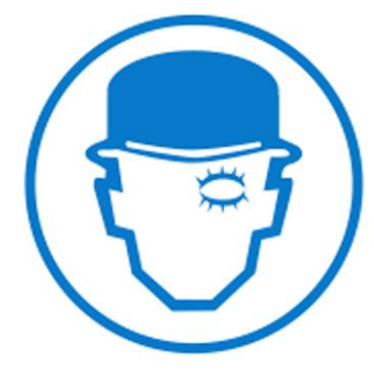

REVISTA TRANSGRESSÕES: CIÊNCIAS CRIMINAIS EM DEBATE, V.5, N.2, MAIO DE 2017

Nosso sistema de controle racial/social apresenta duas faces, ambas com resultados positivos em relação à sua programação racista. No Direito Penal declarado, a seletividade racial é demonstrada pelos dados oficiais do DEPEN que expõem sua "clientela": os negros (pretos e pardos, seguindo a classificação do IBGE) representam, até junho de 2014, 67\% da população encarcerada, o que significa que dois em cada três presos são negros. ${ }^{10}$

Já em nosso Direito Penal paralelo, seu sucesso é unânime pela letalidade direcionada e limitada apenas em termos geográficos, pois a produção de cadáveres pela agência policial a torna uma das que mais mata no mundo, sendo que o número de suas vítimas é superior ao de muitas guerras declaradas. Dito de modo claro, se para os brancos a presença policial significa segurança, para os negros é completamente ao contrário, representando alto risco de vida.

O extermínio do "Ser negro" por meio da assimilação e renegação ancestral faz parte da programação militar pós "seleção policizante" (ZAFFARONI, 1991, 138), caracterizada pelo recrutamento dos integrantes das agências policiais na mesma raça/classe que forma sua "clientela", treinando e condicionando-os a criminalizar (menos) e executar (mais) seus "iguais" a partir da divisão maniqueísta apolítica que pulveriza o racismo no conflito "mocinhos" versus "bandidos", impossibilitando qualquer consciência (racial e de classe) ou identificação entre ambos, proibindo qualquer coalizão que impulsione o potencial identitário necessário a uma mobilização coletiva emancipatória.

A assimilação, com suas falsas promessas e quase nenhum privilégio, forjou o paradigma do escravo leal que o transforma em capitão do mato pelo sonho de redenção por ter nascido negro através da objetificação do corpo (do outro) negro, demonstrando que é o mesmo lado negro e pobre que mata e morre diariamente.

O Direito Penal Paralelo exerce suas práticas desumanizantes por dentro de todos os quadros teóricos, onde a guerra racial (não) declarada é a mesma desde a construção da corporação policial, mantendo-se fiel às suas origens, já que a função da Guarda Real de

\footnotetext{
${ }^{10}$ Em verdade, os números reais são bem maiores, pois São Paulo não enviou seus dados ao Ministério da Justiça.
} 


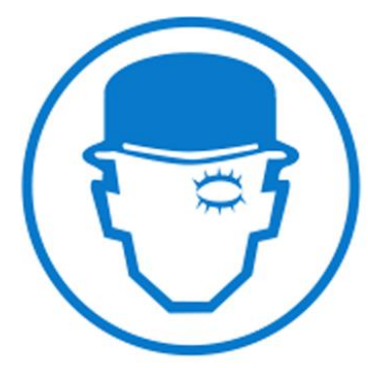

REVISTA TRANSGRESSÕES: CIÊNCIAS CRIMINAIS EM DEBATE, V.5, N.2, MAIO DE 2017

Polícia, no início do século XIX, era manter a ordem com as "Ceias de Camarão"11, substituídas, hoje, pelo extermínio, a regra de um "Estado Democrático e de Direito" é fator básico da cifra negra naturalizada, sempre crescente e quase nunca questionada.

Com a redenção de Cam, o Estado brasileiro substituiu aquela maldição pela do Drácula, sob a qual a "saúde pública" necessita, diariamente, de sangue (negro). A lógica inconstitucional exterminante de nossa "guerra contra as drogas" é chancelada pelo Judiciário, que autoriza, desde a priori, a ignorância do bem jurídico mais valioso (?), legitimada pelo discurso do "inimigo" construído racialmente, demonstrando que nossa "justiça" não possui qualquer obstáculo em seu olhar apurado, deslocando o fiel da balança de acordo com a pigmentocracia.

Essa guerra permanece, irrefutavelmente, perdida, se correlacionarmos seu fundamento declarado e a estratégia adotada, porém, em seu objetivo latente (?) o sucesso é absoluto: o extermínio daquele encontrado em toda e qualquer esquina marginal(izada). De outra face, o Judiciário, orientado pelo racismo estrutural que fundamenta a construção (in)consciente da subjetividade de seus membros, no qual as manifestações e representações racistas são infinitas, é o responsável por transformar o cárcere no outro lugar do negro.

A objetificação de corpos que mantém sempre viva a gênese escravocrata do Estado Brasileiro, tangente a todo ordenamento jurídico que tutela os Direitos Humanos, se projeta ao sistema sócio-educativo transformando-o em um Sistema Penal para menores na prática, evidenciando o punitivismo narcísico que (re)funcionaliza o imbrincamento existente entre suas características, ideologias, instrumentos e falsos discursos, pois é incapaz de ressocializar quem nem ao menos foi socializado, re-educar que nunca foi educado, reintegrar quem jamais foi integrado por uma sociedade excludente.

A violência institucional-estrutural é o cartão de visita estatal às crianças e adolescentes selecionados por esse sistema, não possuindo qualquer outro direito que não a exclusão, a violência e a morte, a faceta real do Direito Penal menorizado e igualmente dicotomizado. Segundo a Organização Mundial de Saúde, o Brasil é o $4^{\circ}$ país em homicídios de crianças e adolescentes, e a "clientela" da terceira maior população encarcerada do mundo

11 Torturas públicas nas quais as vítimas eram literalmente "descascadas" até sua carne ficar exposta. (BATISTA, V., 2003, p. 141). 


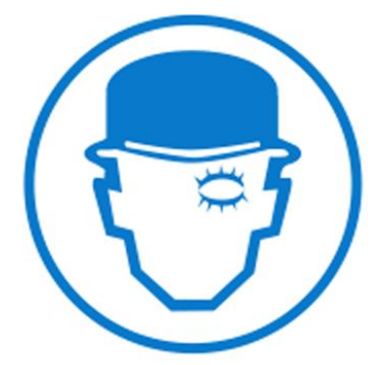

REVISTA TRANSGRESSÕES: CIÊNCIAS CRIMINAIS EM DEBATE, V.5, N.2, MAIO DE 2017

já nos possibilita antever quem será atirado nas prisões já superlotadas se a redução da maioridade penal for aprovada pelo Congresso Nacional.

Sob o discurso reducionista encontramos o paradigma racial-etiológico e a privatização do sistema penitenciário como pagamento das dívidas de campanha de muitos parlamentares (financiadas por construtoras/administradoras de estabelecimentos penais), contexto que nos aproxima do sistema atuarial estadunidense (que já aponta uma revisão em seu sistema penitenciário privado federal e na política de drogas de alguns Estados), além de ser um projeto político eugênico. Estamos à beira da criminalização e encarceramento em escala industrial da população negra, cuja mão de obra será usada por empresas que exploram o setor. A relação simbiótica entre o capitalismo e escravismo confere (re)funcionalização de ambos em uma equação cujo resultado sempre é negativo ao negro!

Nosso Sistema Penal Paralelo (Direito Penal e Sistema Sócio-educativo) nos mostra que a lição de Nina Rodrigues foi muito bem aprendida, afinal, não importa se a maioridade penal será reduzida ou não, eis que em sua prática só existe a limitação territorial, uma vez que somente é exercida nos lugares do negro (áreas marginalizadas e cárcere), onde, desde a promulgação da "Carta Cidadã", temos, ao menos, uma chacina por ano. A "Pátria educadora" prefere encarcerar uma única pessoa a um custo de R\$ 3.312/mês em um estabelecimento penal federal, enquanto um estudante de uma faculdade pública requer, em média, R\$1.498,00/mês.

O Mapa da Violência 2016 revela que ser negro no Brasil é ter uma arma, diuturnamente, apontada para sua cabeça, sem nem ao menos saber onde ela está, evidenciando o que o Movimento Negro (organizado ou não) secularmente denuncia e não é ouvido: o resultado da programação racista/genocida é (sempre) crescente, só recebendo atenção quando pesquisadores brancos a apontam.

Um cenário de violência e morte que se agiganta com a aprovação, pela comissão especial da Câmara dos Deputados, de alterações no Estatuto do Desarmamento, renomeado de Estatuto de Controle de Armas de Fogo. O texto-base reduz para 21 anos a idade mínima para a compra de armas e autoriza a posse e o porte de armas de fogo para pessoas que respondam a inquérito policial ou a processo criminal. 


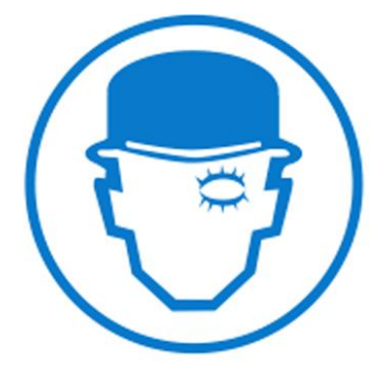

REVISTA TRANSGRESSÕES: CIÊNCIAS CRIMINAIS EM DEBATE, V.5, N.2, MAIO DE 2017

Considerando o poder aquisitivo médio da raça/classe dominante (em face do (quase) silogismo existente entre negro/pobre que recai sobre a maioria da população brasileira), a aquisição legal permitirá ao "cidadão de bem” proteger sua propriedade, a si próprio e seus interesses. O genocídio negro e indígena, nossas marcas genéticas, serão exponenciados em mais uma manobra para manutenção da ordem.

Consoante o exposto alhures, no país das maravilhas raciais, "raça" é fator criminógeno e genocida, consolidados pela banalização e (in)visibilidade do extermínio negro que atinge, também, grande parte de nossa elite crítica. Essa "desatenção" em relação à nossa realidade racial (apesar da imediata, fácil e unânime identificação de nossa "clientela penal"), uma postura de negação de sua marginalidade, mantém a antiga tradição de "traduzir" as teorias centrais, desconsiderando nossas especificidades, pela qual continuamos a ouvir "cifra negra", seletividade penal (e não racial), ordem social (e não racial/social).

Inseridos nessa condição, apontamos para uma verdadeira esquizofrenia que ignora o racismo como fonte de tensões, conflitos e violências, naturalizando a dominação e o monopólio enunciativo dos lugares de fala e ensino, obstáculos à conscientização dos seus inúmeros privilégios proporcionados pela branquitude.

Um presente herdado e ofertado por um mundo monocromático forjado pelo "mascaramento" (MBEMBE, 2014, p. 95) que oculta, nega e dissimula sua própria natureza racista, enquanto todo o histórico genocida negro, de quase quatro séculos, é escamoteado em sua profundidade e efeitos, sendo lugar comum e sintomático o medo e a preocupação com o período ditatorial, quando o paradigma objetificante foi utilizado contra os brancos (principalmente a elite branca), negando ou diminuindo alguns de seus privilégios, sendo o direito à vida o mais importante.

Devemos desvelar nosso racismo mal mascarado, reformulando conceitos e abrindo caminho para o seu (re)conhecimento como processo político genocida histórico e atemporal que transforma aquela mãe gentil (de poucos) em uma madrasta cruel (para a maioria), onde a necropolítica escravocrata foi redefinida pelo "excedente" populacional de corpos cuja força vital deixou de gerar riqueza, sendo que uma existência desvalida e inabsorvível pela 


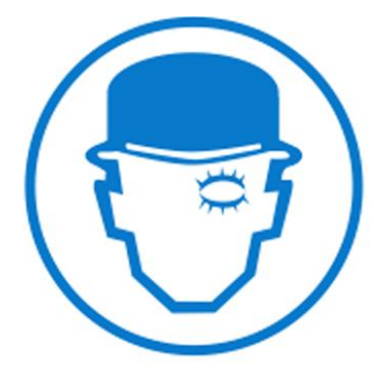

REVISTA TRANSGRESSÕES: CIÊNCIAS CRIMINAIS EM DEBATE, V.5, N.2, MAIO DE 2017

exploração capitalista, impulsiona o extermínio negro como sinônimo de segurança e bem estar da raça/classe dominante.

Em nossa margem, é sobre uma das maiores populações negras do mundo (a maioria dominada, apontada erroneamente como "minoria"), que toda violência, naturalizada e autorizada, recai como instrumento de controle racial, estando ainda a serviço dos sinhôs em estamentos solidificados, subjugada, sobrevivendo em subempregos e "desfrutando" de sua subcidadania.

O silêncio é uma imprescindível arma na manutenção da Casa Grande, lição imortalizada com Anastácia ${ }^{12}$, símbolo máximo da funcionalidade de todas as máscaras (re)utilizadas e (re)significadas, histórica e sistematicamente.

\section{REFERÊNCIAS}

ANDRADE, Vera Regina Pereira de. Pelas mãos da criminologia: o controle penal para além da (des)ilusão. Rio de Janeiro: Revan, 2012.

BARATTA, Alessandro. Criminologia crítica e crítica do direito penal: introdução à sociologia do direito penal. 6. ed. Rio de Janeiro: Revan Instituto Carioca de Criminologia, 2011.

Direitos humanos: entre a violência estrutural e a violência penal. Fascículos de Ciências Penais: Porto Alegre, n. 2, p. 44-61, abr./maio/jun. 1993.

BATISTA, Nilo. Os sistemas penais brasileiros. In: ANDRADE, Vera Regina Pereira de. (Org.) Verso e reverso do controle penal: (des)aprisionando a sociedade da cultura punitiva. Florianópolis: Fundação Boiteux, 2002.

BATISTA, Vera Malaguti. Difíceis ganhos fáceis: droga e juventude pobre no Rio de Janeiro. Rio de Janeiro: Revan, 1998.

O medo na cidade do Rio de Janeiro: dois tempos de uma história. 2 ed. Rio de Janeiro: Revan, 2003.

\footnotetext{
${ }^{12}$ Nascida em Minas gerais, a escrava Anastácia, por se opor, lutar e resistir ao sistema escravocrata e, o quanto pode, às investidas sexuais de seus senhores, foi condenada a usar uma máscara de folha-de-flandres (que fazia parte do patrimônio das fazendas e das casas-grandes) pelo resto de sua vida, retirada apenas para alimentação. Medo, punição exemplar e ciúme das mulheres brancas foram fundamentais para a manutenção da máscara e demais violências que só cessaram com sua morte.
} 


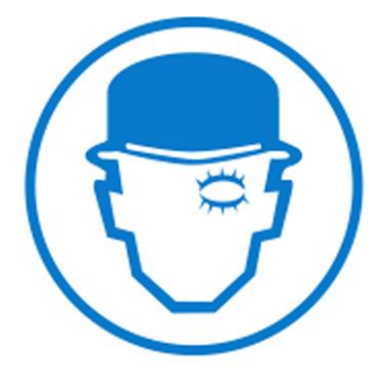

REVISTA TRANSGRESSÕES: CIÊNCIAS CRIMINAIS EM DEBATE, V.5, N.2, MAIO DE 2017

BOAHEN, Albert Adu. (Ed.). História geral da África, VII: África sob dominação colonial, 1880-1935. 2. ed. rev. Brasília: UNESCO, 2010.

CARLINI, Elisaldo Luiz de Araujo; RODRIGUES, Eliana; GALDURÓZ, José Carlos E.

Cannabis sativa L. e substâncias canabinóides em medicina. São Paulo: CEBRID - Centro Brasileiro de Informações Sobre Drogas Psicotrópicas, 2005.

CORRÊA, Mariza. As ilusões da liberdade: a Escola Nina Rodrigues e a antropologia no Brasil. 2. ed. rev. Bragança Paulista: Editora da Universidade São Francisco, 2001.

DUARTE, Evandro Charles Piza. Criminologia e racismo: introdução à criminologia brasileira. Curitiba: Juruá, 2011.

FANON, Frantz. Os condenados da terra. Tradução: José Laurênio de Melo. Rio de Janeiro: Civilização Brasileira, 1968.

FERNANDES, Florestan. O negro no mundo dos brancos. São Paulo: Difusão Européia do Livro, 1972.

FLAUZINA, Ana Luiza Pinheiro. Corpo negro caído no chão: o sistema penal e o projeto genocida do estado brasileiro. Dissertação (Mestrado em Direito), Universidade de Brasília, DF, 2006. Disponível em:

http://repositorio.unb.br/bitstream/10482/5117/1/2006_AnaLuizaPinheiroFlauzina.pdf

Acesso em 14 de janeiro 2016.

FREITAS, Décio. O escravismo brasileiro. 3. ed. Porto Alegre, Mercado Aberto, 1991.

GENELHÚ, Ricardo. O médico e o direito penal. vol. 1: introdução histórico-criminológica. Rio de Janeiro: Revan, 2012.

HERNANDEZ, Leila Leite. A África na sala de aula: Visita à História Contemporânea. São Paulo: Selo Negro, 2005.

GONZALEZ, Lélia. A categoria político-cultural de amefricanidade. In: Tempo Brasileiro. Rio de Janeiro, no. 92/93 (jan./jun.). 1988, p. 69-82.

KAUFMANN, Roberta Fragoso Menezes. Ações afirmativas à brasileira: necessidade ou mito?: uma análise histórico-juridico-comparativa do negro nos Estados Unidos da América e no Brasil. Porto Alegre: Livraria do Advogado, 2007.

LOMBROSO, Cesare. L'uomo bianco e l'uomo di colore: Letture sull'origine e la varietà delle razze umane. Bologna, Archetipolibri - CLUEB, 2012. 


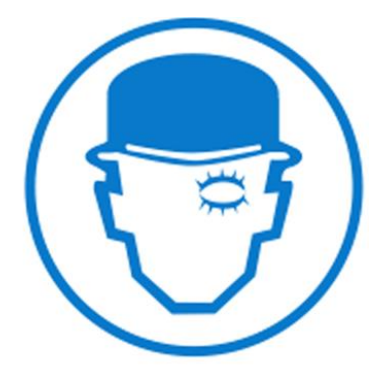

REVISTA TRANSGRESSÕES: CIÊNCIAS CRIMINAIS EM DEBATE, V.5, N.2, MAIO DE 2017

MELOSSI, Dario; PAVARINI, Massimo. Cárcere e fábrica: as origens do sistema penitenciário (séculos XVI-XIX). 2 ed. Rio de Janeiro: Revan.

MENEGAT, Marildo. Estudo sobre ruínas. Rio de Janeiro: Revan, 2012.

MBEMBE, Achille. Crítica da Razão Negra. Trad. Marta Lança. Lisboa: Antígona, 2014.

Necropolitica seguido de Sobre El Governo Privado Indirecto. Santa Cruz de

Tenerife. Melusina. 2011.

MUNANGA, Kabengele. Negritude: usos e sentidos. 2. ed. São Paulo: Atica, 1988.

NASCIMENTO, Abdias do. O genocídio do negro brasileiro: processo de um racismo mascarado. Rio de Janeiro: Paz e Terra, 1978.

NASCIMENTO, Elisa Larkin. O tempo dos povos africanos: suplemento didático da linha do tempo dos povos africanos. IPEAFRO - SECAD/MEC - UNESCO, 2007.

RIBEIRO, Darcy. O povo brasileiro: a formação e o sentido do Brasil. São Paulo:

Companhia das Letras, 1995.

RODRIGUES, Raimundo Nina. As raças humanas e a responsabilidade penal no Brasil. 3. ed. Salvador: Livraria Progresso, 1957.

Os africanos no Brasil. Centro Edelstein de Pesquisas Sociais: Rio de Janeiro, 2010.

SAAD, Luísa Gonçalves. "Fumo de negro": a criminalização da maconha no Brasil (c. 18901932). Salvador, 2013. Dissertação (Mestrado em História) - Universidade Federal da Bahia. Disponível em:

https://repositorio.ufba.br/ri/bitstream/ri/13691/1/DISSERTA\%C3\%87\%C3\%830\%20LUISA \%20SAAD.pdf Acesso em: 25 de fevereiro de 2015.

SANTOS, Joel Rufino. A metamorfose do negro. In: COSTA, Haroldo; LOPES, Nei;

SANTOS, Joel Rufino (Orgs.). Nação Quilombo. Rio de Janeiro: ND Comunicação, 2010.

SCHUCMAN, Lia Vainer. Entre o encardido, o branco e o branquíssimo: branquitude, hierarquia e poder na cidade de São Paulo. São Paulo: Annablume, 2014.

SCHWARCZ, Lilia Moritz. O espetáculo das raças: cientistas, instituições e questão racial no Brasil - 1870-1930. São Paulo: Companhia das Letras, 2012.

SOZZO, Máximo. Viagens culturais e a questão criminal. Tradução Sérgio Lamarão. 1. ed. Rio de Janeiro: Revan, 2014. 


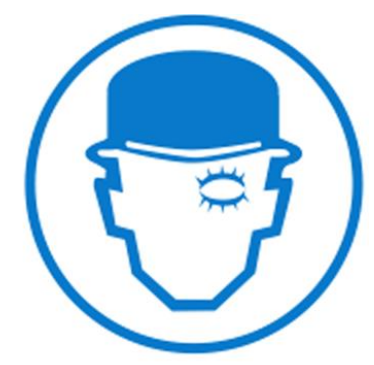

REVISTA TRANSGRESSÕES: CIÊNCIAS CRIMINAIS EM DEBATE, V.5, N.2, MAIO DE 2017

ZAFFARONI, Eugênio Raúl. Criminología. Aproximación desde una margen. Bogotá: Temis, 1988.

Em busca das penas perdidas: a perda da legitimidade do sistema penal. Rio de Janeiro: Revan, 1991.

TERMINATOR HOMELAND: THE BRAZILIAN GENOCIDE PROJECT.

\begin{abstract}
The present article delineates a locus of speech commited to a Brazilian Criminology and our racial marginal realism that intends to shed light on the cause-effect relation between the current massive extermination of black people and Brazilian racism. Such relation is redefined as a historical and continuous political project, resulting from a congenital logic of extermination, both explicit and implicit. It finds in our "war on drugs" its newest legitimation, a complete success that exposes our racial/social control system's racist programming, alongside with the criminal clientele. The ideological strength that maintains the socially established, with pre-settled places, race structure almost intact and unchangeable is constantly reinforced by the pulverization of the race issue, that, despite the notorious outcomes that racism produces to our "Criminal Laws", it's not placed as a key player. Such context has provoked a major racial deficit, we live in a society that since its discovery/concealment has not been projected nor prepared to deal with the black person as an equal - a world in which only one race monopolizes power, keeping its domination. An ignored reality that reinforces our racism with ideological politics that supports the childish tale of a racial wonderland. By not naming racism as it is and by not facing it, we project, beyond our horinzons, a scenery of fear and terror.
\end{abstract}

Keywords: Genocide. Racism. Brazilian Criminology. Marginal Realism. 